\title{
Alteration of the N-Formyl-Methionyl-Leucyl- Phenylalanine-Induced Response in Cystic Fibrosis Neutrophils
}

\author{
THIERRY KEMP, ANGÈLE SCHRAM-DOUMONT, RENÉ VAN GEFFEL, RAPHAËL KRAM, ${ }^{1}$ AND \\ CLAUDE SZPIRER \\ Université Libre de Bruxelles, Départment de Biologie Moléculaire, B-1640 Rhode-St-Genèse, and Hôpital de \\ Braine l'Alleud, B-1420 Braine l'Alleud [R.V.G.], Belgium
}

\begin{abstract}
In order to determine whether cystic fibrosis neutrophils are affected in their secretory functions, lysosomal enzyme release and chemiluminescence (light emission from cells) were assayed in patients' cells and compared with those in normal control cells. We observed a decreased response of cystic fibrosis neutrophils in $\beta$ glucuronidase release and chemiluminescence after stimulation by $\mathrm{N}$-formyl-methionyl-leucyl-phenylalanine. There was no significant correlation of these results with the clinical score nor with the medical treatment. On the other hand, responses to the calcium ionophore $\mathrm{A23187}$ and to opsonized zymosan showed no significant difference between normal and cystic fibrosis subjects in lysosomal enzyme release. $\mathbf{N}$-formyl-methionyl-leucyl-phenylalanine receptor alterations did not seem involved in the observed effect as demonstrated by Scatchard plot analysis of $\mathrm{N}$ formyl-methionyl-leucyl-phenylalanine binding to these receptors. These results clearly demonstrate a difference between normal and cystic fibrosis neutrophils in release and chemiluminescence responses to $\mathrm{N}$-formyl-methionylleucyl-phenylalanine stimulation, a difference that might be located in the plasma membrane as both responses are membrane dependent. (Pediatr Res 20: 520-526, 1986)
\end{abstract}

\section{Abbreviations}

$\mathrm{CF}$, cystic fibrosis

FMLP, N-formyl-methionyl-leucyl-phenylalanine

TFP, trifluoperazin

TMB-8, 8-(N,N-diethylamino)-octyl 3,4,5-trimethoxybenzoate

LDH, lactate dehydrogenase

$K_{D}$, dissociation constant

$\mathbf{R}_{\mathrm{N}}$, number of receptor per cell

$\mathrm{CF}$ is an autosomal recessive disease characterized by abnormal exocrine functions resulting mainly in pancreatic insufficiency, chronic pulmonary disease, and elevated levels of electrolytes in sweat. The CF gene was recently mapped on chromosome $7(1-4)$.

Received April 15, 1985; accepted January 30, 1986.

Correspondence C. Szpirer, Université Libre de Bruxelles, Départment de Biologie Moléculaire, Rue des Chevaux, 67, B-1640 Rhode-St-Genèse, Belgium.

Supported by the Belgian Foundation for Medical Scientific Research. We also thank the Belgian Cystic Fibrosis Association and the Kiwanis Bruxelles SaintMichel Club for their generous support. C.S. is research associate of the Belgian FNRS.

${ }^{1}$ Deceased.
The basic defect for this exocrine dysfunction is still unknown and little progress has been made in the definition of the pathogenesis of the disease, perhaps, as previously pointed out (5) because most biochemical investigations have involved analyses of either complex fluids (saliva, plasma, serum) or cells (fibroblasts, leucocytes, erythrocytes) that were chosen for their availability from patients, while $\mathrm{CF}$ is a disease affecting primarily epithelial cells and not the cell types (mesodermal origin) mainly examined to date.

However, because it is difficult to study epithelial cells in culture, polymorphonuclear neutrophil leucocytes could be helpful in the investigation of the primary biochemical defect in CF. Indeed, it has long been demonstrated that the neutrophil, when treated with cytochalasin $B$, resembles a secretory cell (6) in which biochemical pathways leading to the extracellular release of lysosomal enzymes have striking similarities to those involved in exocytosis from exocrine glands (7-9). In this respect, neutrophils can be used as a convenient system to approach the biochemical inborn error of $\mathrm{CF}$, if one assumes that the disease actually affects one of the common pathways in neutrophil and exocrine tissue secretions.

Herein, we report an analysis of various aspects of the stimulus-secretion coupling in CF and normal neutrophils using three different stimuli: opsonized zymosan, FMLP and ionophore A23187. Opsonized zymosan is made of a yeast wall polysaccharide coated with complement $\mathrm{C} 3 \mathrm{~b}$ and $\mathrm{C} 3 \mathrm{bi}$ fragments and $\mathrm{IgG}$ (10); FMLP is a synthetic chemotactic peptide which is a potent activator of neutrophil functions (11) and A23187 is a calcium ionophore which promotes a rise of intracellular calcium levels, a crucial step for neutrophil activation (6). Both FMLP and opsonized zymosan activate neutrophils via membrane receptors while A23187 makes the plasma membrane permeable to calcium, and promotes calcium influx, due to the large transmembrane calcium gradient between the inside and the outside of the cell $(6,10,12)$.

In this study, we have compared two physiological responses (exocytosis and chemiluminescence) of normal and CF neutrophis and identified an altered response in CF cells to one of the stimuli we used.

\section{MATERIALS AND METHODS}

All chemicals were obtained from Sigma Chemical Co., St Louis, MO, except Lymphoprep (Nyegaard and Co. A/S, Oslo, Norway), RPMI 1640 medium (Flow Laboratories, Irvine, Scotland), Plasmagel (Bellon Laboratoire SA, Neuilly-sur Seine, France), cytochalasin B (Aldrich Chemical Co., Inc., Milwaukee, WI), FMLP (Union Chimique Belge, Bioproducts, Brussels, Belgium), cyano $\left({ }^{57} \mathrm{Co}\right)$ cobalamin (Amersham, Int., Amersham, England), ${ }^{3} \mathrm{H}-\mathrm{FMLP}$ (NEN, Boston, MA), ionophore A23187, 
superoxide dismutase and LDH test kit (Boehringer Mannheim, Mannheim, Germany). All water-insoluble compounds were dissolved in dimethyl sulfoxide (Merck, Darmstadt, Germany) or ethanol to make appropriate stock solutions such that the final concentration of DMSO or ethanol in the reaction mixtures was $0.1 \%(\mathrm{v} / \mathrm{v})$, a concentration found not to affect any of the assays performed or the viability of cells as measured by trypan blue dye exclusion or $\mathrm{LDH}$ release.

Preparation of human neutrophils. Human neutrophils were purified from heparinized $(50 \mathrm{U} / \mathrm{ml})$ venous blood $(10-30 \mathrm{ml})$ of healthy volunteers or of CF patients by Ficoll-Metrizoate density gradient (Lymphoprep) centrifugation as described by Böyum (13). After plasmagel sedimentation, contaminating erythrocytes were removed by hypotonic lysis.

The washed neutrophils were resuspended at a final concentration of $4 \times 10^{6}$ cells $/ \mathrm{ml}$ in phosphate buffer $(7.4 \mathrm{mM}$ $\mathrm{Na}_{2} \mathrm{HPO}_{4} ; 2.6 \mathrm{mM} \mathrm{KH}_{2} \mathrm{PO}_{4}$ ), $\mathrm{pH} 7.4$, containing $140 \mathrm{mM} \mathrm{NaCl}$, $1 \mathrm{mM} \mathrm{CaCl}_{2}$, and $1 \mathrm{mM} \mathrm{MgCl}$ (buffer $\mathrm{P}$ ). The cell suspension was equilibrated for at least $30 \mathrm{~min}$ at $37^{\circ} \mathrm{C}$ prior to stimulation.

Patients' selection. Healthy control subjects consisted of males and females (61 and 39\%, respectively) with ages ranging from 5 to $21 \mathrm{yr}$ (mean age $13.7 \pm 2.5$ ). They had no family members affected by $\mathrm{CF}$, no recent viral or bacterial infection, nor had they received any medication within the 2 wk before the study. CF patients were selected from the Hôpital de Braine l'Alleud (Belgium). The patients' ages ranged from 3 to $25 \mathrm{yr}$ with a mean age of $15.2 \pm 3.8$. Sex distribution was $40 \%$ males and $60 \%$ females. At the time of study, the patients ranged from severely ill to slightly affected, as evaluated using the NIH clinical score (14). All CF patients were taking pancreatic enzymes supplements (Cotazym, Viokase). Depending on their state of health, some patients were taking mucolytics ( $\mathrm{N}$-acetyl cysteine) and antibiotics (neomycin, bacitracin, gentamycin, ticarcillin, tobramycin, or ceftazidime). All patients tested were volunteers, and their consent (or the consent of their parents) had been obtained. This study was approved by the local ethical committee.

Incubation procedures. Zymosan was boiled ( $30 \mathrm{~min})$, washed in phosphate-buffered saline $\left(7.4 \mathrm{mM} \mathrm{Na} 2 \mathrm{HPO}_{4} ; 2.6 \mathrm{mM} \mathrm{Na}\right.$ $\left.\mathrm{H}_{2} \mathrm{PO}_{4}\right), \mathrm{pH} 7.2,1 \mathrm{mM} \mathrm{MgCl}$, and incubated with serum (50 $\mathrm{mg} / \mathrm{ml}$ ) at $37^{\circ} \mathrm{C}$ for 30 min before being washed and resuspended in buffer $\mathrm{P}$ at the required concentration of opsonized zymosan. Incubations were initiated by addition of either A23187 $\left(10^{-9}\right.$ $\left.10^{-4} \mathrm{M}\right)$, opsonized zymosan $(1.0-25.0 \mathrm{mg} / \mathrm{ml})$ or FMLP $\left(10^{-10}\right.$ $\left.10^{-3} \mathrm{M}\right)$ and were terminated by cooling in melting ice followed by centrifugation in a Sorval type A centrifuge $(1000 \times g$ for 5 min), and the supernatant removed for assay. Triplicate incubations were performed for all treatments. When required, cells were preincubated with cytochalasin B $(5 \mu \mathrm{g} / \mathrm{ml})$ or with inhibitors for $15 \mathrm{~min}$ prior to stimulation.

Assay of $\beta$-glucuronidase was made using phenolphtalein glucuronate as substrate (15). Results are expressed as the percentage of total cellular enzyme activity obtained when cells were completely lysed with $0.2 \%(\mathrm{v} / \mathrm{v})$ Triton $\mathrm{X}-100$. Cellular integrity was monitored in all experiments by the exclusion of trypan blue dye and by the release of a cytoplasmic marker (lactate dehydrogenase); this release was always $<5 \%$ except for A23187 stimulation where values were below $10 \%$.

Vitamin B12-binding protein. This protein was assayed as described by Roos et al. (16).

Chemiluminescence assay. Measurements of native chemiluminescence (i.e. in the absence of luminol or of lucigenin) were made with a Packard liquid scintillation counter working in the out of coincidence mode in a partially darkened room and at a constant room temperature of $25^{\circ} \mathrm{C}$. (Contrary to the light "flashes" produced by radioactive particles in scintillating solutions, the light emitted by phagocytes consists of "single" photons; these photons give rise to pulses occurring randomly in only one of the phototubes of liquid scintillation counters and are therefore eliminated by coincidence circuit if the latter is not left out.) One-ml aliquots of neutrophil suspensions containing $4 \times 10^{6}$ neutrophils were added to siliconized scintillation vials. Stock cell suspensions were made in buffer $P$ supplemented with $1 \%(\mathrm{v} / \mathrm{v})$ inactivated fetal calf serum, $0.1 \%(\mathrm{w} / \mathrm{v})$ glucose, and amino acids (Minimal essential medium amino acids solution, Gibco Europe, Paisley, Scotland). After equilibration for at least $30 \mathrm{~min}$ at $37^{\circ} \mathrm{C}, 0.1 \%(\mathrm{w} / \mathrm{v})$ bovine serum albumin was added to the cells and unstimulated neutrophils were monitored for their chemiluminescence background. To measure the sample chemiluminescence, the neutrophil reaction mixture was kept in a $37^{\circ} \mathrm{C}$ warming block until the addition of FMLP. Each vial was counted immediately after the stimulation at 15-s intervals for as long as $20 \mathrm{~min}$, with slight reduction in the reaction mixture temperature.

${ }^{3} \mathrm{H}-\mathrm{FMLP}$ binding assay. ${ }^{3} \mathrm{H}-\mathrm{FMLP}$ binding to neutrophils was measured by a rapid filtration technique (17). Briefly, after incubation of neutrophils in presence of ${ }^{3} \mathrm{H}$-FMLP at $24^{\circ} \mathrm{C}$, cells were filtered through Whatman $(\mathrm{GF} / \mathrm{C})$ glass fiber filters using a rapid filtration device. The filters were washed twice with $5 \mathrm{ml}$ ice-cold buffer $\mathrm{S}\left(20 \mathrm{mM} \mathrm{NaH} \mathrm{PO}_{4}, 123 \mathrm{mM} \mathrm{NaCl}, 1 \mathrm{mM}\right.$ $\mathrm{CaCl}_{2}, 1 \mathrm{~g} /$ liter dextrose), placed in $5 \mathrm{ml}$ of $\mathrm{HP} / \mathrm{b}$ scintillation liquid (Beckman, Palo Alto, CA) and stored overnight before counting radioactivity in a Packard Model 3380 liquid scintillation spectrometer. For the assay, cells were suspended $\left(5 \times 10^{6}\right.$ neutrophils/10 ml) in buffer B (same as buffer S, except bovine serum albumin was substituted for dextrose) and were equilibrated for $30 \mathrm{~min}$ at $24^{\circ} \mathrm{C}$ prior to the assay. Nonspecific binding was defined as the amount of binding not inhibited by a 1000 fold excess of unlabeled FMLP (17) and was usually from 5 to $20 \%$ of the total counts bound. Specific binding was defined as the total amount of ${ }^{3} \mathrm{H}-\mathrm{FMLP}$ bound minus the nonspecific binding.

Statistical analysis. Student's $t$ test (for unpaired samples) or paired $t$ test (for paired samples) was used to test for significant differences between normal and CF cells. For groups of unequal size, $F$ ratios were determined by a one-way analysis of variance. Nonparametric comparisons (median test, Mann-Whitney test, sign test) were also performed to confirm the results of the $t$ tests on small numbers of data.

\section{EXPERIMENTAL RESULTS}

Lysosomal enzyme release. Normal and CF patient neutrophils exhibited similar $\beta$-glucuronidase activity. The Vmax and the $\mathrm{Km}$ of the normal cell enzyme were not different from the corresponding values of the CF cell enzyme. Similarly, the basal levels of $\beta$-glucuronidase secretion did not differ among the two groups of cells and were (mean $\pm \mathrm{SD}$ ): $7.3 \pm 2.2 \%$ of total activity in the absence of cytochalasin $B$ and $10.3 \pm 1.9 \%$ in the presence of cytochalasin B for normal cells, and $7.3 \pm 3.5 \%$ in the absence of cytochalasin $B$ and $10.4 \pm 3.9 \%$ in the presence of cytochalasin $\mathrm{B}$ for CF cells. On the other hand, FMLP-stimulated exocytosis, measured by $\beta$-glucuronidase release, was significantly lower in neutrophils from CF patients than in neutrophils from healthy controls (Fig. 1). The dose response curve shows that this difference in exocytosis was observed over a wide range of FMLP concentrations. However, for next experiments, we have only used $10^{-6}$ M FMLP, since this concentration is sufficient to give, in most experiments, a clear difference between normal and $\mathrm{CF}$ neutrophil release.

Analysis of numerous preparations of CF neutrophils $(n=57)$ and normal neutrophils $(n=71)$ stimulated with $10^{-6}$ M FMLP gave values (mean $\pm \mathrm{SD}$ ) of $\beta$-glucuronidase release of $46.4 \pm$ 7.1 and $59.8 \pm 10.0 \%$, respectively, with $p<0.0005$. In the CF group, neutrophils from different patients, but also from the same patient at different times and varying degrees of severity of the disease, were tested. It was obvious that no correlation existed between the response of CF neutrophils to FMLP and the state of the patients (NIH clinical score); strongly diminished re- 


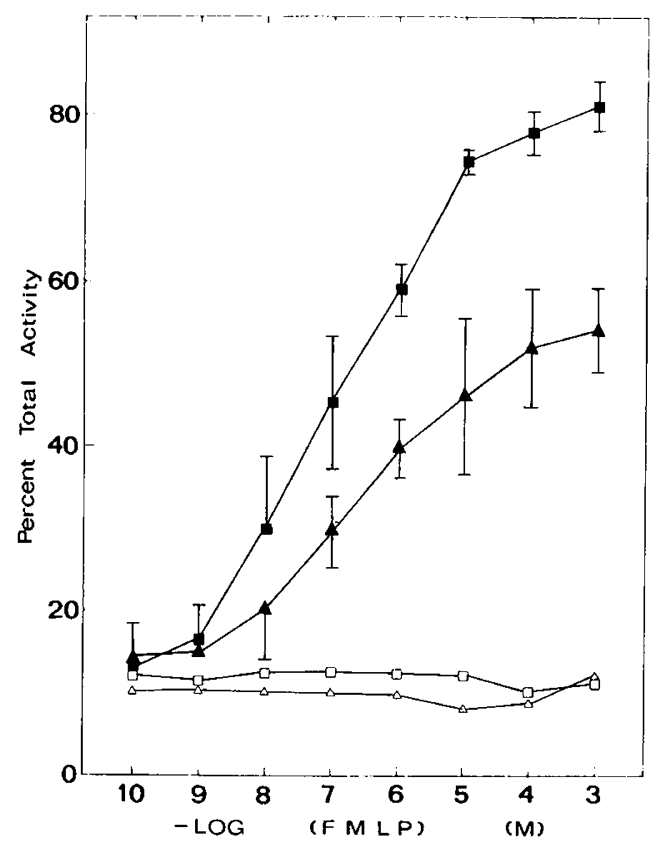

Fig. 1. Effect of FMLP concentration on $\beta$-glucuronidase release. The experimental conditions are as described in "Materials and methods." Cells from normal $(\boldsymbol{\square}, \square)$ and $\mathrm{CF}(\boldsymbol{\Lambda}, \Delta)$ neutrophils were preincubated $(\boldsymbol{\square}, \mathbf{\Lambda})$ with $5 \mu \mathrm{g} / \mathrm{ml}$ cytochalasin B for $10 \mathrm{~min}$ at $37^{\circ} \mathrm{C}$ before addition of FMLP or stimulated with FMLP alone $(\square, \triangle)$.

sponses to FMLP stimulation were observed with CF neutrophils from lightly affected patients and vice versa, responses close to control ones were observed with CF neutrophils from severely affected donors; in addition, cells from the same patient taken at different times gave a reproducible secretory response. Similarly age and sex were not factors affecting the magnitude of the secretory response. Figure 1 also indicates that the $\mathrm{ED}_{50}$ (concentration of stimulus inducing half-maximal stimulable release) is approximately the same for normal $\left(5.3 \times 10^{-8} \mathrm{M}\right)$ and $\mathrm{CF}(6.0$ $\left.\times 10^{-8} \mathrm{M}\right)$ cells. Since differences in the amount of enzyme release could be due to differences in the rate of exocytosis, we examined the time course of $\beta$-glucuronidase secretion for each stimulus we used in normal and CF neutrophils. No difference was found in the temporal activation of maximal release (Fig. 2).

On the other hand, neutrophils from patients with CF exhibited exocytosis responses to opsonized zymosan (Fig. 3) or A23187 (Fig. 4) stimulation similar to those of normal neutrophils. Since cytochalasin B appeared to be necessary for FMLP. induced lysosomal enzyme release (Fig. 1) (6), all three stimuli were tested in the presence or in the absence of this drug; our results show that cytochalasin $\mathrm{B}$ was enhancing secretion responses to A23187 and opsonized zymosan stimulation and thus cannot be involved in the decreased response to FMLP stimulation of CF neutrophils release. None of the stimuli we used (FMLP, A23187, opsonized zymosan) had greater effect on normal neutrophils than on $\mathrm{CF}$ neutrophils in increasing $\mathrm{LDH}$ release from the cells. The amount of LDH released probably reflects lysis of a small number of cells and we thus conclude that a difference in $\beta$-glucuronidase exocytosis cannot be explained by a preferential lytic effect of the stimulus on one cell population.

Since FMLP provokes both the release of enzymes from primary (azurophil) granules, such as $\beta$-glucuronidase, and of constituents of secondary (specific) granules, such as the vitamin B12-binding protein (6), we then asked whether CF neutrophils also exhibit an abnormal FMLP-induced release of vitamin B12binding protein. The comparison of 10 pairs of $C F$ and control neutrophils showed that the total content of vitamin B12-binding
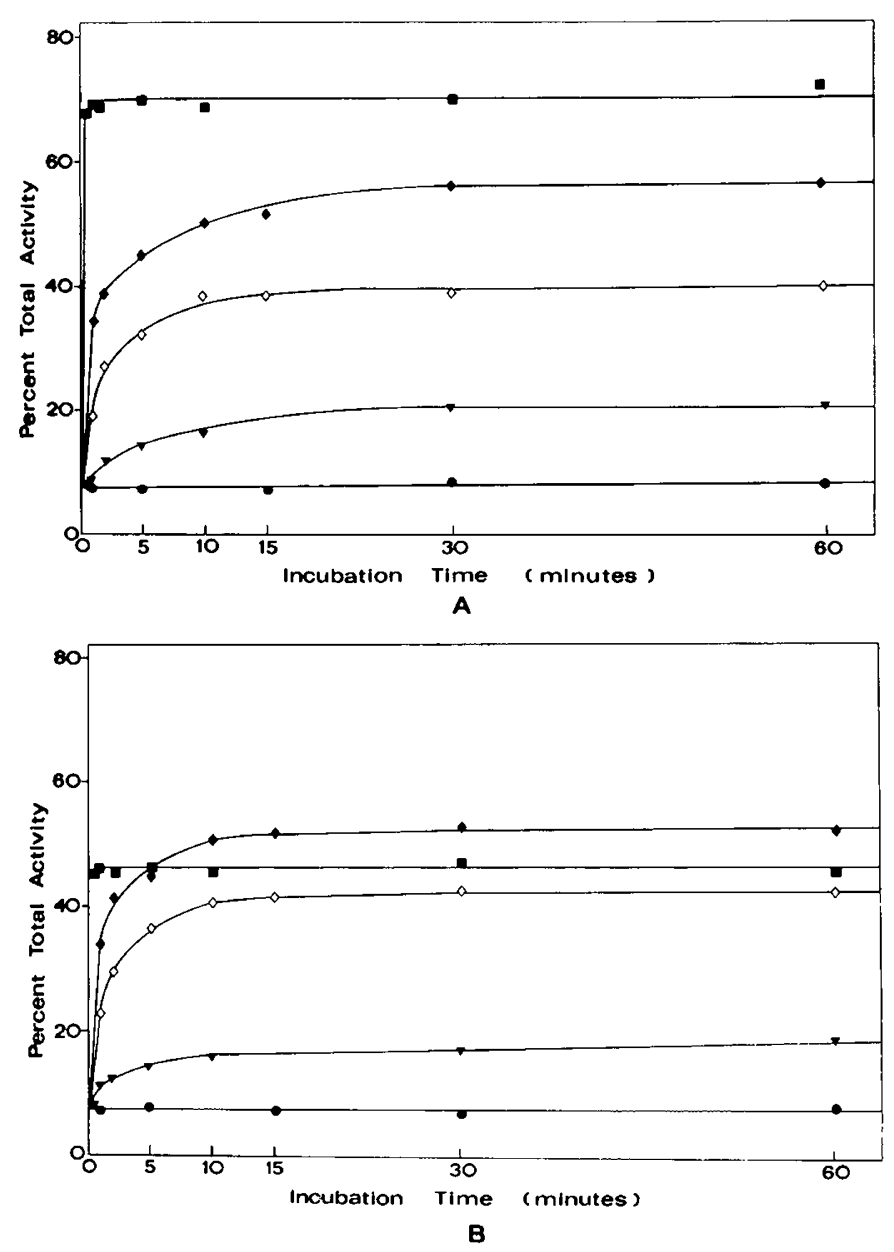

Fig. 2. Time course of FMLP-( $\square)$, A23187-( $\diamond \diamond)$, and opsonized zymosan- $(\nabla)$ induced release of $\beta$-glucuronidase from normal neutrophils $(A)$ and $C F$ neutrophils $(B)$. The experimental conditions are as described in "Materials and methods." Except for $\diamond$, cells were preincubated with $5 \mu \mathrm{g} / \mathrm{ml}$ cytochalasin B for $10 \mathrm{~min}$ at $37^{\circ} \mathrm{C}$ before addition of the stimulus. 0 , resting cells. Stimulus concentrations were $10^{-6} \mathrm{M}, 5 \times 10^{-5}$ $\mathrm{M}$, and $10 \mathrm{mg} / \mathrm{ml}$, respectively. Curves are taken from one representative experiment.

protein was slightly higher in CF cells than in control cells: 306 \pm 60 versus $251 \pm 47 \mathrm{pg} / 10^{6}$ cells. FMLP-induced release was similar in both categories: $34.7 \pm 9.0 \%$ in $\mathrm{CF}$ neutrophils and $37.9 \pm 7.6 \%$ in control cells. However, as described above, these CF samples exhibited a reduced release of $\beta$-glucuronidase (43.7 \pm 7.3 versus $60.4 \pm 5.8 \%$ )

Calcium and lysosomal enzyme release. Calcium plays a pivotal role in the stimulus-secretion coupling of the neutrophils (18). Both intracellular and extracellular calcium concentrations are of importance for lysosomal enzyme release (19). In order to determine whether calcium metabolism is affected in CF neutrophils, we studied the effects of calcium metabolism disturbance on normal and CF neutrophil functions. Table 1 indicates that CF neutrophils were as sensitive as normal cells to variations of extracellular calcium concentrations, suggesting that the permeability of the plasma membrane to this cation is unaltered in $\mathrm{CF}$ cells. Intracellular calcium, and particularly membrane-bound calcium, is the main source of calcium in activation of the neutrophil functions. Using various inhibitors which, in one way or another, interact with plasma membrane, we have investigated the effect of perturbations of this pool of calcium. Three inhibitors were tested. 1) Ethacrynic acid, an inhibitor of the calcium stimulated ATPase (calcium pump) in a large variety of cell types (20); this enzyme is responsible for the maintenance of cytosolic 


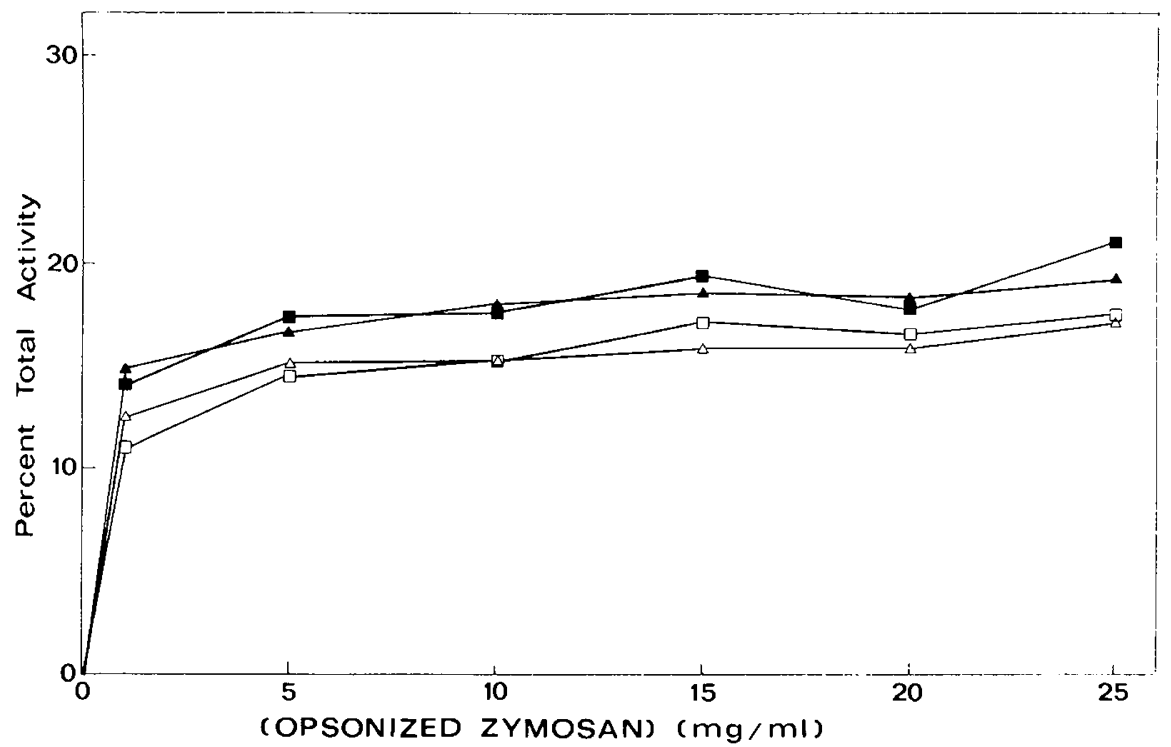

Fig. 3. Effect of opsonized zymosan on $\beta$-glucuronidase release. The experimental conditions were as described in "Materials and methods." Cells from normal $(\boldsymbol{\square}, \square)$ and CF $(\boldsymbol{\Lambda}, \Delta)$ were preincubated $(\boldsymbol{\square}, \mathbf{\Lambda})$ with $5 \mu \mathrm{g} / \mathrm{ml}$ cytochalasin B for $10 \mathrm{~min}$ at $37^{\circ} \mathrm{C}$ before addition of opsonized zymosan or stimulated with opsonized zymosan alone $(\square, \Delta)$.

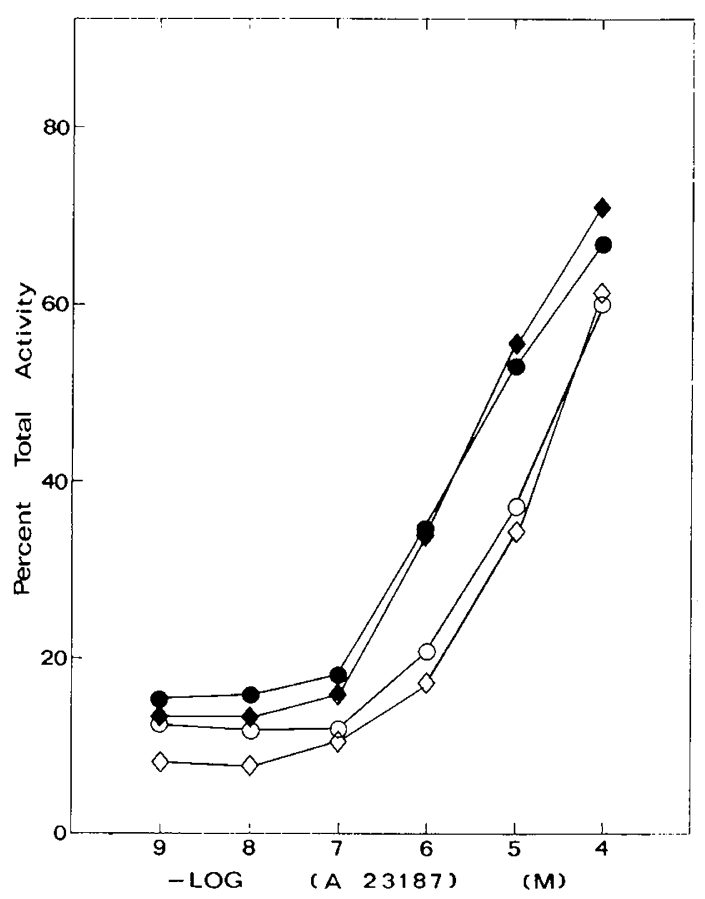

Fig. 4. Effect of $\mathrm{A} 23187$ on $\beta$-glucuronidase release. The experimental conditions are as described in "Materials and methods." Cells from normal $(\bullet, \diamond)$ and $\mathrm{CF}(\bullet, O)$ neutrophils were preincubated $(\bullet, \bullet)$ with $5 \mu \mathrm{g} / \mathrm{ml}$ cytochalasin $\mathrm{B}$ for $10 \mathrm{~min}$ at $37^{\circ} \mathrm{C}$ before addition of $\mathrm{A} 23187$ or stimulated with $\mathrm{A} 23187$ alone $(\diamond, \mathrm{O})$.

free calcium level in neutrophils and we shall assume that, as in other cells, the neutrophil calcium ATPase is inhibited by ethacrynic acid. 2) TMB-8 or 8-(dimethyl-amino)-3,4,5-trimethoxybenzoate-l-octanol, an inhibitor of the release of intracellular calcium from membranes (which has no effect on calcium uptake;21); TMB-8-also inhibits protein kinase C (22). 3) TFP (trifluoperazin) an inhibitor of calmodulin-dependent processes and, mainly, of other processes via its phospholipid-interacting properties (23).

As Table 2 shows, a significant difference was observed between normal and CF neutrophils when two of the inhibitors
Table 1. Effect of extracellular calcium concentration on FMLPinduced $\beta$-glucuronidase release*

\begin{tabular}{ccc}
\hline $\begin{array}{c}\mathrm{CaCl}_{2} \text { added } \\
(\mathrm{mM})\end{array}$ & $\begin{array}{c}\text { Control } \\
\text { neutrophils } \\
(n=5)\end{array}$ & $\begin{array}{c}\text { CF neutrophils } \\
(n=5)\end{array}$ \\
\hline 0.0 & $82.5 \pm 6.2 \%$ & $83.3 \pm 4.9 \%$ \\
0.2 & $93.2 \pm 5.5 \%$ & $82.7 \pm 17.0 \%$ \\
0.5 & $94.3 \pm 6.4 \%$ & $92.9 \pm 7.7 \%$ \\
0.7 & $92.4 \pm 8.4 \%$ & $91.0 \pm 4.6 \%$ \\
1.0 & $100 \%$ & $100 \%$ \\
2.0 & $67.6 \pm 24.7 \%$ & $77.5 \pm 3.7 \%$ \\
3.0 & $2.6 \pm 2.2 \%$ & $2.1 \pm 0.7 \%$ \\
\hline
\end{tabular}

* At an external calcium concentration of $1 \mathrm{mM}$, the FMLP-induced release of $\beta$-glucuronidase is taken as $100 \%$.

were used (TFP and TMB-8): CF neutrophils were slightly less sensitive to these two inhibitors than control neutrophils. This difference appeared limited to FMLP stimulation.

Chemiluminescence. The microbicidal action of neutrophils proceeds in part through the production of highly reactive oxygen metabolites as superoxide anions $\left(\mathrm{O}_{2}^{-}\right), \mathrm{H}_{2} \mathrm{O}_{2}$ or the hydroxyl radical (OH.) (24). The membrane NADPH oxidase is responsible for the major oxidative activity of the neutrophil (25). A wide variety of phagocytic particles and soluble agonists can stimulate the oxidative processes (18), but chemotactic peptides are relatively weak agonists. Oxidative microbicidal activity is associated with the generation of light, a phenomenon called chemiluminescence (24), and activation of the NADPH oxidase can thus be monitored by quantitating light emission. Comparison of the chemiluminescence response of normal and $C F$ neutrophils to FMLP stimulation (in the absence of cytochalasin B) indicated a similar kinetics for both cells, but CF cells showed a weaker peak than normal neutrophils (Fig. 5). Although the magnitude of the chemiluminescence response varied from one experiment to another (different cell preparations), the CF neutrophil response was generally below the normal response within the same experiment. Pretreatment of the cells with cytochalasin $B$ affected neither the kinetics of the peak nor the observed difference (although the peak is increased about 3-fold). Figure 6 shows the distribution of the results obtained from eight experiments for the release and chemiluminescence responses of 
Table 2. Effect of calcium antagonists on $\beta$-glucuronidase release response of neutrophils to FMLP, A23187, and opsonized zymosan*

\begin{tabular}{ccccc}
\hline & & \multicolumn{3}{c}{ Inhibitort } \\
\cline { 3 - 4 } Stimulus & Neutrophils $(n=7)$ & TMB-8 & TFP & EA \\
\hline FMLP & Control & $61.3 \pm 8.6 \neq$ & $50.7 \pm 7.1 \S$ & $29.0 \pm 8.4 \|$ \\
A23187 & CF & $72.2 \pm 12.9$ & $65.0 \pm 9.8$ & $30.5 \pm 7.4$ \\
& Control & $73.4 \pm 11.6 \|$ & $74.7 \pm 18.0 \|$ & $28.7 \pm 4.5 \|$ \\
Opsonized zymosan & CF & $68.5 \pm 5.3$ & $70.6 \pm 8.3$ & $27.8 \pm 5.6$ \\
& Control & $130.7 \pm 20.5 \|$ & $117.9 \pm 15.0 \|$ & $71.7 \pm 11.3 \|$ \\
& CF & $122.3 \pm 19.2$ & $111.6 \pm 20.9$ & $63.9 \pm 13.7$ \\
\hline
\end{tabular}

* The results are expressed as percentage $( \pm \mathrm{SD})$ of stimulated neutrophil release in the absence of inhibitors. Stimuli concentrations were as follows: $10^{-6} \mathrm{M}$ FMLP, $510^{-5} \mathrm{M}$ A23187, and $10 \mathrm{mg} / \mathrm{ml}$ opsonized zymosan.

$\dagger$ Inhibitors concentrations were as follows: $510^{-4} \mathrm{M}$ TMB-8, $510^{-5} \mathrm{M}$ TFP, and $1 \mathrm{mM}$ ethacrynic acid (EA).

$¥$ Significant difference $(p<0.05)$ (based on paired $t$ test).

$\S$ Significant difference $(p<0.005)$ (based on paired $t$ test)

$\|$ Difference not significant.

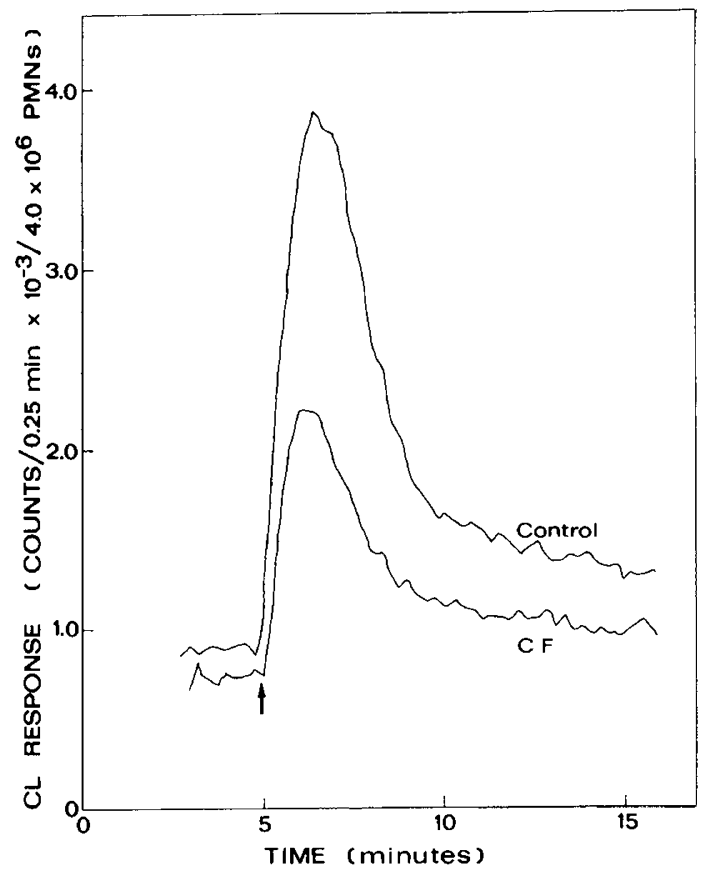

Fig. 5. Chemiluminescence response of control and CF neutrophils. The experimental conditions are as described in "Materials and methods." Representative results from eight experiments for control and CF cells are shown. The arrow indicates the time of addition of $10^{-6} \mathrm{M}$ FMLP.

normal and CF neutrophils to FMLP stimulation. The difference in the responses of these matched pairs of control and CF cells is evident. Superoxide dismutase $(100 \mu \mathrm{g} / \mathrm{ml})$ inhibited almost completely FMLP-induced chemiluminescence while sodium azide ( $1 \mathrm{mM}$ ), an inhibitor of myeloperoxidase (a lysosomal enzyme involved in chemiluminescence production), had either no or a slight inhibitory effect on this chemiluminescence, indicating that the chemiluminescence response monitored in FMLP-stimulated cells was essentially limited to the membrane.

FMLP receptors. The impaired response of CF neutrophils to FMLP could be due to a defect in the number or the quality of the FMLP receptors. Figure 7 shows that, although the apparent $K_{D}$ is similar in normal and CF neutrophils the $R_{N}$ was increased in CF neutrophils. These results were confirmed in 12 experiments $($ mean $\pm S D): R_{N}=54,850 \pm 26,100$ and $K_{D}(n M)=3.75$ \pm 0.85 for control cells and $R_{N}=74,200 \pm 32,200$ and $K_{D}=$ $4.11 \pm 1.48$ for $C F$ cells (for $\mathrm{R}_{\mathrm{N}} p<0.01$; for $\mathrm{K}_{\mathrm{D}}$, difference not significant by the Student's $t$ test). These results clearly demon- strate that the impaired response of CF neutrophils cannot be explained by a lack of FMLP receptors nor by a lower affinity of these receptors.

\section{DISCUSSION}

In this study, we have compared the release of lysosomal $\beta$ glucuronidase and vitamin B12-binding protein from normal and CF neutrophils in order to identify a possible secretory defect in the latter cells. We found that responses to opsonized zymosan and to the calcium ionophore A23187 were identical in both cell preparations, but that a significant difference could be demonstrated between normal and CF neutrophils in FMLP-induced $\beta$-glucuronidase release. This difference is either a direct consequence of the presence of the CF gene or a secondary effect of the disease. Since we found no correlation between the severity of the illness and the magnitude of the observed difference we favor the first hypothesis. The effect of a possibly abnormal environment of CF neutrophil that would affect the responsiveness of these cells is difficult to dismiss [CF serum has been shown to promote exocytosis and calcium uptake in neutrophils $(26,27)]$. However, a possible desensitization of FMLP receptors in $\mathrm{CF}$ cells (resulting, for instance from the presence of stimulatory factors in CF serum) is unlikely for several reasons. First, since the neutrophils were thoroughly washed for these studies, it is clear that the continued presence of serum is not required for the abnormal response to be observed; in addition, preincubation of normal cells with CF serum did not affect the response of these cells to FMLP (data not shown). Second, young CF patients who had not yet developed lung infection showed the same alteration as chronically infected patients. Third, total content of $\beta$-glucuronidase (primary granules) and of vitamin B12-binding protein (secondary granules) was not lower in $\mathrm{CF}$ neutrophils, suggesting that these cells were not prestimulated. Finally, we have measured FMLP receptors in number and affinity in normal and CF neutrophils. Affinity of CF neutrophil receptors was not significantly different from that of normal receptors, while the number of FMLP receptors per CF neutrophil was increased, although not very significantly $(p<0.01)$ compared to normal cells. This strongly indicates that the altered response of CF neutrophils to FMLP stimulation reflects an intrinsic defect rather than an overstimulated cell state, and that this defect occurs at a level beyond that of the receptor. It is also unlikely that desensitization results from an elevated level of intracellular cyclic AMP, a cyclic nucleotide known to inhibit neutrophil responses (6), since it has been demonstrated that basal adenylate cyclase activity and cyclic AMP level are normal in CF neutrophils $(28,29)$.

Native chemiluminescence in neutrophils is stimulated by FMLP and results from the production of reactive oxygen species by activated NADPH oxidase, a membrane enzyme. We ob- 

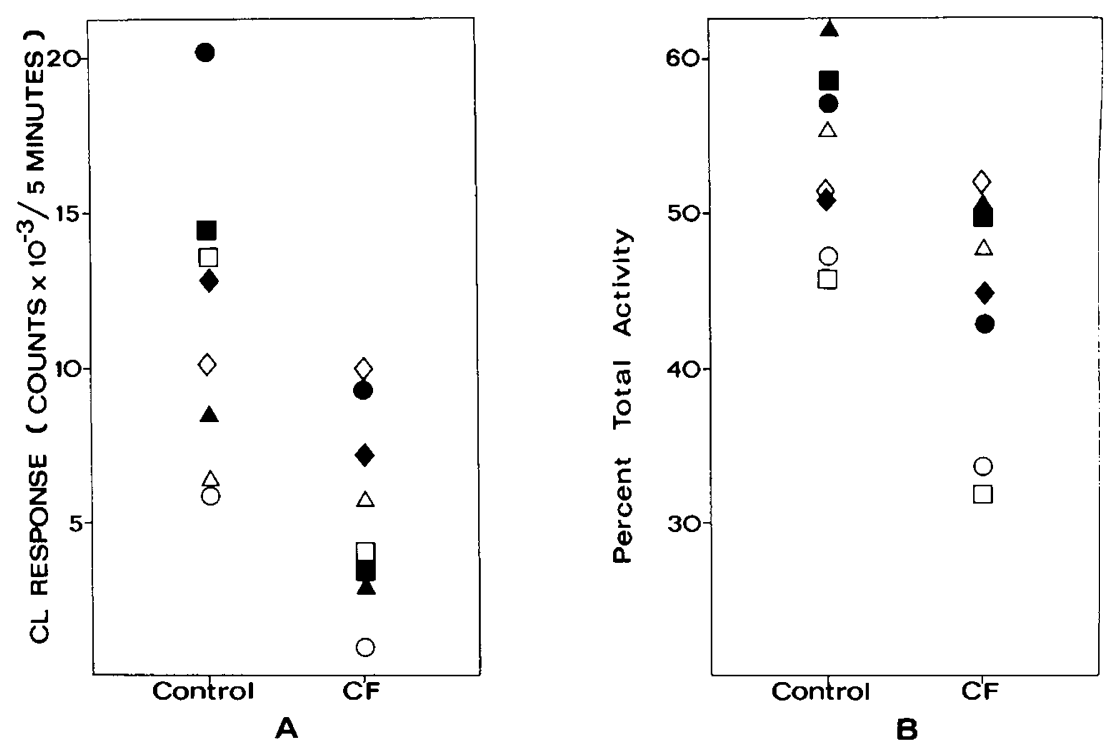

Fig. 6. Comparison of $\beta$-glucuronidase release and chemiluminescence responses of normal and CF neutrophils to FMLP stimulation within one experiment. Cells were stimulated with $10^{-6} \mathrm{FMLP}$ (in the presence of $5 \mu \mathrm{g} / \mathrm{ml}$ cytochalasin B for release experiments). One $s y m b o l$ represents normal and CF neutrophil responses from the same day experiment. $A$, chemiluminescence; $B$, release.

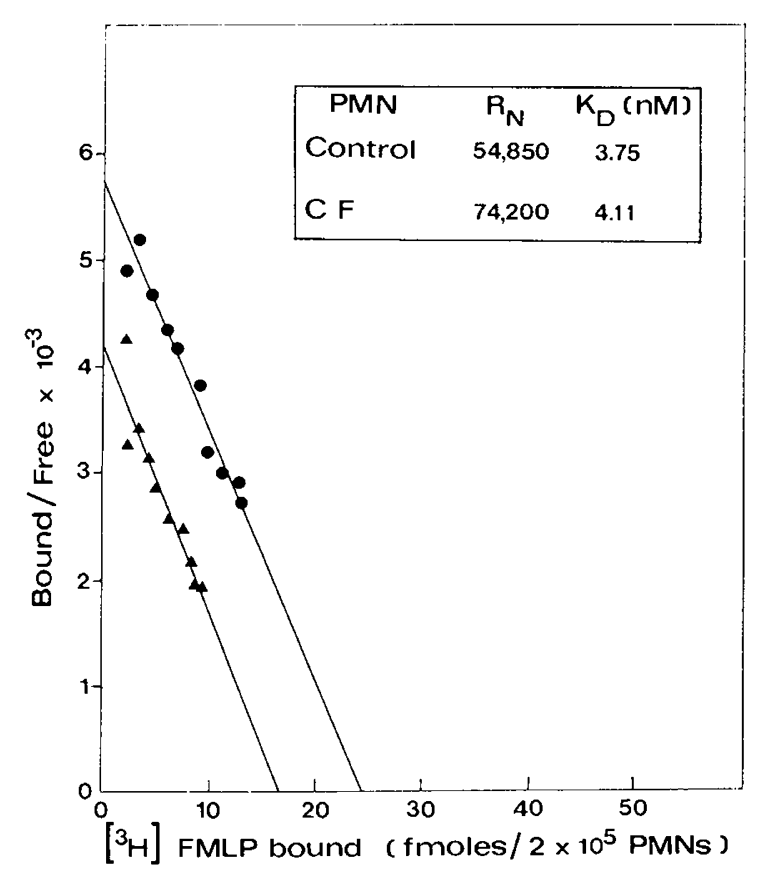

Fig. 7. Scatchard plot of specific binding of ${ }^{3} \mathrm{H}$-FMLP. The data of a representative experiment with control $(\boldsymbol{\Lambda})$ and $\mathrm{CF}(\bullet)$ neutrophils are shown. The inset shows the mean values of the $R_{N}$ and of the $K_{D}$ from 12 experiments. For conditions, see "Materials and methods." The CF neutrophils used in this experiment were also shown to be defective in $\beta$-glucuronidase release and chemiluminescence just as in the preparations mentioned in the text and in the other figures.

served an impaired native chemiluminescence in CF neutrophils stimulated with FMLP, as in the case of $\beta$-glucuronidase exocytosis. Earlier observations revealed a normal granulocyte oxidative response using opsonized zymosan as stimulus (30). NADPH oxidase activity thus seems to be specifically impaired in FMLPstimulated cells, again like $\beta$-glucuronidase exocytosis.

The rise of cytoplasmic-free calcium is one of the most important physiological events detected in stimulated neutrophils, the release of plasma membrane-bound calcium being the main signal in the stimulus-secretion coupling (19). The critical role of calcium in this coupling is well documented in a variety of cells (7-9) and CF (31). In this work, we have shown that the active intracellular pool in CF neutrophils is apparently not abnormally reduced: these cells, even in the absence of extracellular calcium are still responsive to FMLP and opsonized zymosan. In this context, it is striking that ethacrynic acid, an inhibitor of the plasma membrane calcium ATPase activity (20), has the same effect on CF and control neutrophils (Table 2). Other authors have reported that the calcium-stimulated ATPase activity is decreased in CF cells (32). Our results indicate that if this alteration is general, it is not accompanied by a differential sensitivity of the calcium ATPase to ethacrynic acid.

On the other hand, we showed that $C F$ neutrophils are more resistant than control neutrophils to TMB-8 and TFP inhibition. This result suggests the possibility that calcium metabolism and/ or protein kinase $C$ (both are affected by TMB- 8 and TFP) are altered, directly or indirectly in CF neutrophils. Calcium metabolism has been suggested to be central in the pathogenesis of $\mathrm{CF}$ by several authors $(26,31-34)$ and changes in mitochondrial calcium concentrations have been described in CF cells $(31,33$, 34; but see also 35,36 ). However, our observations on TMB-8 inhibition cannot be explained by abnormal mitochondrial calcium concentrations since mitochondrial calcium does not seem to participate in the rise of cytoplasmic calcium concentration (31). Protein kinase $\mathrm{C}$ is involved in the exocytosis (37) and chemiluminescence (38) processes, and its activity is dependent on phospholipid metabolism (39). In this respect, it might be significant that abnormal fatty acid turnover has been observed in the red blood cell phospholipids of most CF patients (40). Further studies on calcium metabolism and the activity of protein kinase $C$ in stimulated $C F$ neutrophils should contribute to identify the defective step in the FMLP-induced response of CF neutrophils.

In summary, we have demonstrated that CF neutrophils differ from control neutrophils in at least two aspects of their response to FMLP, namely $\beta$-glucuronidase exocytosis and NADPH oxidase-dependent chemiluminescence. This alteration is not a consequence of deficient FMLP receptors in CF neutrophils.

Acknowledgments. The authors are grateful to Professor E. Schram (Laboratory of Biochemistry; V.U.B.) for his help in the chemiluminescence tests and to M. Rivière for technical help. We thank Dr. Ellen Hsu for thoughtful reading of the manuscript. 


\section{REFERENCES}

1. Knowlton RG, Cohen-Haguenauer O, Van Cong N, Frézal J, Brown VA, Barker D, Braman JC, Schumm JW, Tsui L-C, Buchwald M, Donis-Keller H 1985 A polymorphic DNA marker linked to cystic fibrosis is located on chromosome 7. Nature 318:380-382

2. White R, Woodward S, Leppert M, O'Connell P, Hoff M, Herbst J, Lalouel JM, Dean M, Vande Woude G 1985 A closely linked genetic marker for cystic fibrosis. Nature 318:382-384

3. Wainwright BJ, Scambler PJ, Schmidtke J, Watson EA, Law H-Y, Farrall M, Cooke HJ, Eiberg H, Williamson R 1985 Localization of cystic fibrosis locus to human chromosome 7cen-q22. Nature 318:384-385

4. Tsui L-C, Buchwald M, Barker D, Braman JC,, Knowlton R, Schumm JW, Eiberg H, Mohr J, Kennedt D, Plavsic N, Zsiga M, Markiewicz D, Akots G, Brown V, Helms C, Gravius T, Parker C, Rediker K, Donis-Keller H 1985 Cystic fibrosis locus defined by a genetically linked polymorphic DNA marker. Science 230:1054-1057

5. Applegarth DA, Bridges MA, 1983 Is cystic fibrosis a disease confined to epithelial cells? Hypotheses 1 1:277-283

6. Weissman G, Smolen JE, Korchak HM, Hoffstein S 1981 The secretory code of the neutrophil. In: Dingle JT, Gordon JL (eds) Cellular Interactions. Elsevier, Amsterdam, North-Holland, pp 15-31

7. Douglas WW 1974 Involvement of calcium in exocytosis and the exocytosisvesiculation sequence. Bichem Soc Symp 39:1-28

8. Kanagasuntheram P, Randle PJ 1976 Calcium metabolism and amylase release in rat parotid acinar cells. Bichem $\mathrm{J}$ 160:547-564

9. Schultz I, Stolze HH 1980 The exocrine pancreas: the role of secretagogues, cyclic nucleotides, and calcium in enzyme secretion. Ann Rev Physiol 42:127-156

10. Goldstein IM, Roos D, Kaplan HB, Weissman G 1975 Complement and immunoglobulins stimulate superoxide production by human leukocytes independently of phagocytosis. J Clin Invest 56:1155-1163

11. Showell HJ, Freer RJ, Zigmond SH, Schiffman E, Aswanikumar S, Corcoran B, Becker EL 1976 The structure-activity relations of synthetic peptides as chemotactic factors and inducers of lysosomal enzyme secretion for neutrophils. J Exp Med 143:1154-1169

12. Gallin JI, Seligmann B 1984 Mobilization of human neutrophil chemoattractant f-Met-Leu-Phe receptors. Fed Proc 43:2732-2736

13. Böyum A 1968 Isolation of mononuclear cells and granulocytes from human blood. Scand J Clin Invest 22(suppl 97):77-89

14. Taussig LM, Kattwinkel J, Friedewald WT, di Sant'Agnese PA 1973 A new prognostic score and clinical evaluation system for cystic fibrosis. J Pediatr 82:380-390

15. Worthington Enzyme Manual 1972. Worthington Biochemical Corp, Freehold, NJ, pp 109-110

16. Roos D, Voetman AA, Meerhof LJ 1983 Functional activity of enucleated human polymorphonuclear leukocytes. J Cell Biol 97:368-377

17. Fletcher MP, Gallin JI 1980 Degranulating stimuli increase the availability of receptors on human neutrophils for the chemoattractant f-Met-Leu-Phe. J Immunol 124:1585-1588

18. Weissmann G, Smolen JE, Korchak HM 1980 Release of inflammatory mediators from stimulated neutrophils. N Engl J Med 303:27-34

19. Smolen JE, Korchak HM, Weissman G 1981 The roles of extracellular and intracellular calcium in lysosomal enzyme release and superoxide anion generation by human neutrophils. Biochim Biophys Acta 677:512-520

20. Vincenzi FF, Hinds TR 1976 Plasma membrane calcium transport and membrane-bound enzymes. In: Martonosi A (ed) The Enzymes of Biological Membranes, Vol 3, Membrane Transport. Plenum Press, New York, pp 261-281

21. Smith RJ, Iden SS 1979 Phorbol myristate acetate-induced release of granule enzymes from human neutrophils: inhibition by the calcium antagonist,
8-(N,N-diethylamino)-octyl 3,4,5-trimethoxybenzoate hydrochloride. Biochem Biophys Res Commun 91:263-27

22. Kojima I, Kojima K,Rasmussen H 1985 Mechanism of inhibitory action of TMB-8 (8-(NN-diethylamino)octyl-3,4,5-trimethoxybenzoate) on aldosterone secretion in adrenal glomerulosa cells. Biochem J 232:87-92

23. Luthra MG 1982 Trifluoperazine inhibition of calmodulin-sensitive $\mathrm{CA}^{2+}$ ATPase and calmodulin-insensitive $\left(\mathrm{Na}^{+}+\mathrm{K}^{+}\right)$- and $\mathrm{Mg}^{2+}$-ATPase activities of human and rat red blood cells. Biochim Biophys Acta 692:271-277

24. Allen RC 1980 Chemiluminescence:an approach to the study of the humoralphagocyte axis in host defence against infection. In: Peng CT, Horrocks DL, Alpen EL (eds) Liquid Scintillation Counting: Recent Applications and Development. Academic Press, New York, pp 377-393

25. Tauber AI 1982 The human neutrophil oxygen armory. Trends Biochem Sci 7:411-414

26. Banschbach MW, Karam AG, Love PK, Hilman BC 1978 Cystic fibrosis serum promotes ${ }^{45} \mathrm{Ca}$ uptake by normal human leukocytes. Biochem Biophys Res Commun 84:922-927

27. Conod EJ, Conover JH, Hirschhorn K 1975 Demonstration of human leukocyte degranulation induced by sera from homozygotes and heterozygotes for cystic fibrosis. Pediatr Res 9:724-729

28. Davis PB, Laundon SC 1980 Adenylate cyclase in leukocytes from patients with cystic fibrosis. J Lab Clin Med 96:75-84

29. Davis PA, Dieckman L, Boat TF, Stern RC, Doershuk CF 1983 Beta adrenergic receptors in lymphocytes and granulocytes from patients with cystic fibrosis. J Clin Invest 71:1787-1795

30. Graft DF, Mischler E, Farrell PM, Busse WW 1982 Granulocyte chemiluminescence in adolescent patients with cystic fibrosis. Am Rev Respir Dis $125: 540-543$

31. Case RM $1984 \mathrm{Ca}^{++}$, stimulus-secretion coupling and cystic fibrosis. In: Lawson D (ed) Cystic Fibrosis Horizons: Proceedings of the 9th International Cystic Fibrosis Congress. Wiley and Sons. Chichester, England, pp $53-67$

32. Katz S $1980 \mathrm{Ca}^{2+}$-transport and $\left(\mathrm{Mg}^{2+}+\mathrm{Ca}^{2+}\right)$-ATPase activity in cystic fibrosis. In: Sturges JM (ed) Perspective in Cystic Fibrosis: Proceedings of the 8th International Cystic Fibrosis Congress. Imperial Press, Missisauga, Ontario, pp 3-14

33. Shapiro BL, Feigal RJ, Lam LF-H 1980 Intracellular calcium and cystic fibrosis. In: Sturgess JM (ed) Perspectives in Cystic Fibrosis: Proceedings of the 8th International Cystic Fibrosis Congress. Imperial Press, Missisauga, Ontario, pp 15-28

34. Sorscher EJ, Breslow JL 1982 Cystic fibrosis: a disorder of calcium-stimulated secretion and transepithelial sodium transport? Lancet 1:368-370

35. Grinstein S, Elder B, Clarke CA, Buchwald M 1984 Is cytoplasmic $\mathrm{Ca}^{2+}$ in lymphocytes elevated in cystic fibrosis? Biochim Biophys Acta 769:270274

36. Waller RL, Bratin WJ, Dearborn DG 1984 Cytosolic free calcium concentration and intracellular calcium distribution in lymphocytes from cystic fibrosis patients. Life Sci 35:775-781

37. White JR, Huang C-K, Hill JM, Naccache PH, Becker EL, Sha'afi RI 1984 Effect of phorbol 12-myristate 13-acetate and its analogue 4-phorbol 12,13-didecanoate on protein phosphorylation and lysosomal enzyme release in rabbit neutrophils. J Biol Chem 259:8605-861 1

38. Fujita I, Irita K, Takeshige K, Minakami S 1984 Diacylglycerol, 1-oleoyl-2acetyl-glycerol, stimulates superoxide-generation from human neutrophils. Biochem Biophys Res Commun 120:318-324

39. Nishizuka Y 1984 The role of protein kinease $C$ in cell surface signal transduction and tumor promotion. Nature 308:693-697

40. Rogiers V, Dab I, Michotte Y, Vercruysse A, Crokaert R, Vis HL 1984 Abnormal fatty acid turnover in the phospholipids of the red blood cell membranes of cystic fibrosis patients (in vitro study). Pediatr Res 18:704709 